\title{
Severe hypoproteinemia as a harbinger of Ménétrier's disease in autoimmune pancreatitis
}

Julio Maria Fonseca Chebli ${ }^{1 *}$, Liliana Andrade Chebli ${ }^{1}$, Tarsila Campanha da Rocha Ribeiro ${ }^{1}$, Pedro Duarte Gaburri ${ }^{1}$

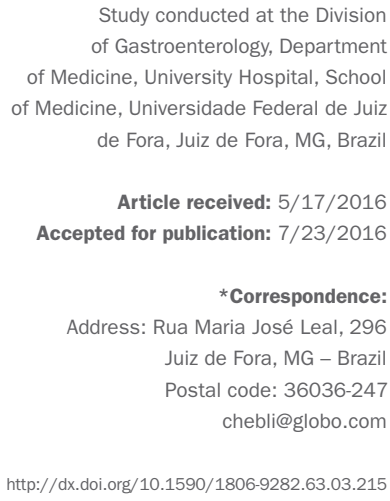

Study conducted at the Division

of Gastroenterology, Department of Medicine, University Hospital, Schoo of Medicine, Universidade Federal de Juiz de Fora, Juiz de Fora, MG, Brazil

Article received: 5/17/2016 Accepted for publication: 7/23/2016 Correspondence: Address: Rua Maria José Leal, 296 Juiz de Fora, MG - Brazil Postal code: 36036-247 chebli@globo.com

\section{SUMMARY}

Ménétrier's disease is an extremely rare disease of unknown etiology causing gastric mucosal hypertrophy and protein-losing gastropathy. Rare cases of this condition have been reported in patients with autoimmune diseases. However, to the best of our knowledge, Ménétrier's disease associated with autoimmune pancreatitis (AIP) has never been reported. We described a case of severe hypoproteinemia as a harbinger of Ménétrier's disease associated with AIP. The patient was successfully treated with octreotide and high-protein diet, which led to symptomatic remission and significant improvement in serum levels of albumin and recovery of the nutritional status. Thus, in AIP patients presenting with severe and persistent hypoproteinemia without apparent cause, clinicians need to consider Ménétrier's disease in the differential diagnosis. In this setting, endoscopic evaluation with histological examination of gastric biopsy material, including a full-thickness mucosal biopsy of involved mucosa, may be helpful in promptly establishing the diagnosis and allowing appropriate and timely therapy.

Keywords: autoimmune pancreatitis, Ménétrier's disease, protein-losing gastropathy.

\section{INTRODUCTION}

Ménétrier's disease is an extremely rare disease of unknown etiology causing gastric mucosal hypertrophy and protein-losing gastropathy. It's more common in adults between 30 and 60 years of age. ${ }^{1}$ Rare cases of this condition have been reported in patients with autoimmune diseases, including ulcerative colitis, systemic lupus erythematosus, ankylosis spondylitis, and chronic lymphocytic gastritis. ${ }^{1-3}$ However, to the best of our knowledge, Ménétrier's disease associated with autoimmune pancreatitis (AIP) has never been reported.

\section{Case report}

A 54-year-old white man presented with a 3-month history of mild epigastric pain following meals, occasional episodes of diarrhea with watery stools, weight loss, and peripheral edema. He had been diagnosed with type 1 AIP three years before and had been managed successfully with prednisone slowly tapered down over the course of three months, followed by low-dose maintenance prednisone ( $5 \mathrm{mg} /$ daily) for 2.5 years. The current treatment included prednisone ( $5 \mathrm{mg}$ daily) and enzyme replacement therapy with 50,000 units of lipase per meal and 25,000 units per snack. At an appointment in our gastroenterology outpatient clinic, he appeared mildly malnourished (body mass index 18) and presented with edema of the legs and sacral region. There was no history of vomiting, nausea, jaundice, fever, or recent antibiotic use. Results of blood analysis at this time revealed hemoglobin 11.3 $\mathrm{g} / \mathrm{dL}$, normal WBC and reticulocyte, serum ferritin concentration $55 \mu \mathrm{g} / \mathrm{L}$, transferrin saturation $30 \%$, total protein $3.5 \mathrm{~g} / \mathrm{dL}$, albumin $1.5 \mathrm{~g} / \mathrm{dL}$, C-reactive protein 0.1 $\mathrm{mg} / \mathrm{L}$, serum vitamin B12 level at $390 \mathrm{ng} / \mathrm{L}$, serum IgG4 levels at $85 \mathrm{mg} / \mathrm{dL}$, and serum IgA count at $310 \mathrm{mg} / \mathrm{dL}$. Additionally, serum glucose, alkaline phosphatase, bilirubin, liver transaminases, creatinine, thyroid function, and 24-hour urine protein were normal. Serologic testing, including IgA anti-transglutaminase and IgA anti-endomysial antibodies, and human immunodeficiency virus- 1 and human immunodeficiency virus- 2 antibody tests yielded negative results. Stool cultures for conventional enteric pathogens and ova/parasites were negative, as well 
as three stool tests for Clostridium difficile toxin. A 72-hour fecal fat collection showed $5 \mathrm{~g} / 24$ hours of fat in the stool, and fecal elastase- 1 concentration at $230 \mu \mathrm{g} / \mathrm{g}$ of stool, suggesting normal exocrine pancreatic function. Nevertheless, alpha-1-antitrypsin stool concentration was high, at $495 \mathrm{mg} / \mathrm{mL}$, a surrogate marker for protein-losing gastroenteropathy. A barium swallow (upper gastrointestinal series) depicted polypoid hypertrophic gastric folds predominantly involving the gastric fundus and body with antral sparing (Figure 1). The esophagus and duodenum were apparently normal. An abdominal computed tomography revealed diffusely enlarged rugal folds predominantly on the gastric fundus and body, normal-appearing small bowel, mild ascites in the pelvis and pancreatic atrophy compatible with a late burnt-out phase of autoimmune pancreatitis and/or post-treatment state. An upper gastrointestinal endoscopy showed normal appearance of the esophageal and duodenal mucosa. The gastric mucosa was edematous, erythematous and with significant hypertrophy of folds, particularly in the fundus and body of the stomach. No mass lesion, ulceration, stenosis or obstruction was noted. Multiple gastric biopsy specimens and a full-thickness sample of gastric mucosal were obtained for biopsy. Histopathological examination showed enlarged folds with foveolar hyper- plasia, glandular cystic dilatation and mild focal inflammation with some eosinophils; intestinal metaplasia or dysplasia was absent and there was still a decrease in the number of parietal and chief cells. Evaluation of gastric biopsy specimens was negative for cytomegalovirus inclusion bodies and Helicobacter pylori. Further, modified Steiner silver impregnation stain reveals no spirochetes. For the differential diagnosis of gastric fold thickening, other lab tests were ordered. Thus, a ${ }^{14} \mathrm{C}$-urea breath test for Helicobacter pylori was negative. Moreover, serum VDRL, Treponema pallidum immunofluorescence studies, polymerase chain reaction for cytomegalovirus, and fasting serum gastrin level were unremarkable. A colonoscopy was performed, showing normal colonic mucosa throughout the segments and a normal-appearing terminal ileum. Random colon biopsies showed only nonspecific chronic inflammation. The diagnosis of Ménétrier's disease associated with autoimmune pancreatitis was established.

Our patient was given $40 \mathrm{mg}$ of pantoprazole twice daily, $20 \mathrm{mg}$ of furosemide daily and a high-protein diet. Regardless of this approach, the patient remained without symptomatic improvement and was then ordered octreotide long-acting release (LAR), $20 \mathrm{mg}$, every 28 days. The patient gradually improved; abdominal pain and diarrhea completely resolved and steadily weight gain was evident.

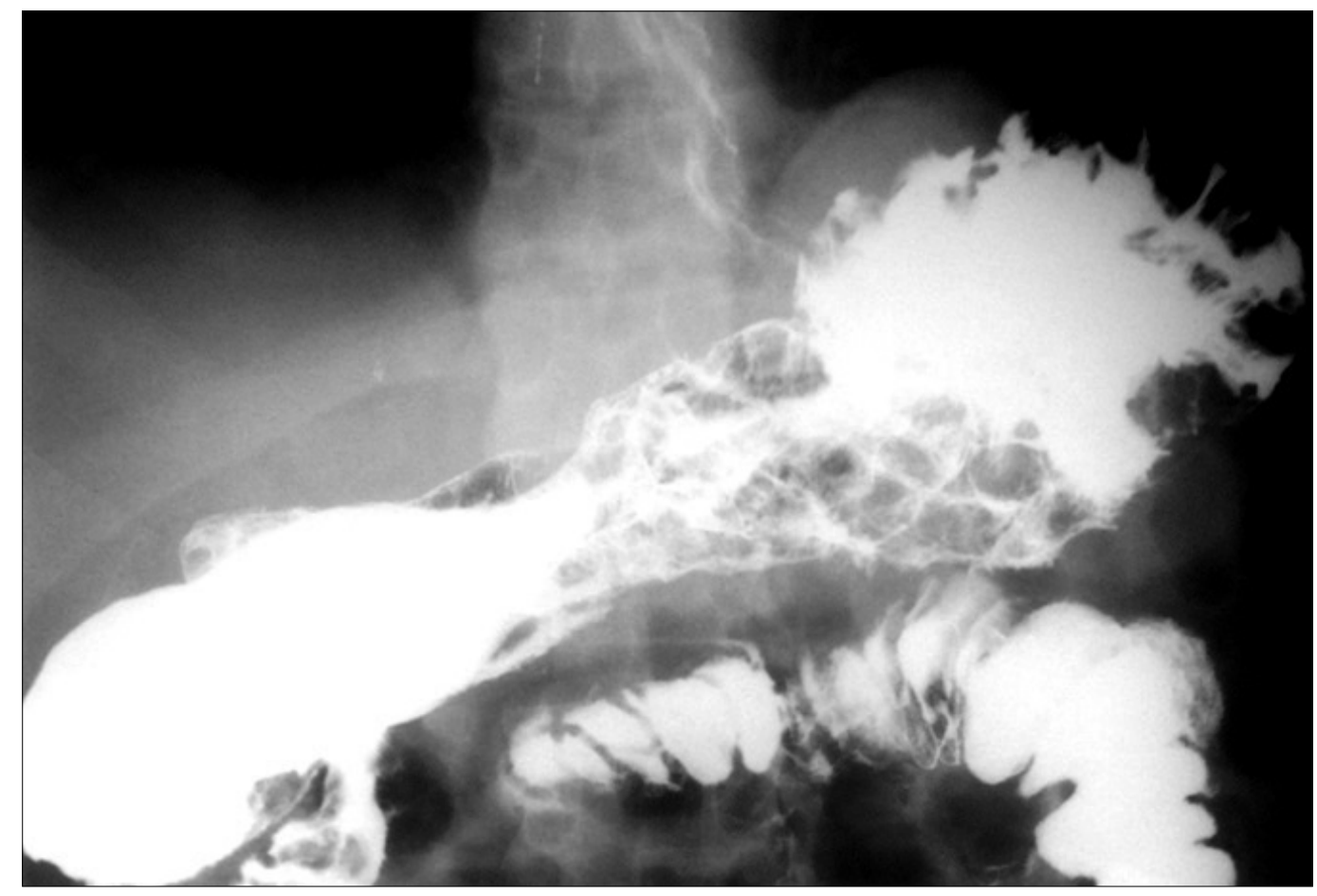

FIGURE 1 Barium swallow (upper gastrointestinal series) showing polypoid hypertrophic gastric folds predominantly involving the gastric fundus and body with antral sparing. 
Three months later, there was complete regression of edema, and the patient remained asymptomatic. His serum albumin level had increased to $2.8 \mathrm{~g} / \mathrm{dL}$ and total protein to $6.5 \mathrm{~g} / \mathrm{dL}$. The patient was instructed to continue octreotide LAR therapy, prednisone $5 \mathrm{mg}$ daily, and follow a high-protein diet. Nowadays, the patient experiences episodes of mild epigastric pain following main meals; however, he has no diarrhea or edema. His serum albumin level remains near $3.0 \mathrm{~g} / \mathrm{dL}$ and total protein $6.7 \mathrm{~g} / \mathrm{dL}$.

\section{Discussion}

Ménétrier's disease is characteristically associated with protein-losing gastropathy and hypochlorhydria, the latter possibly related to overexpression of transforming growth factor-alpha. ${ }^{4}$ Patients may present with epigastric pain, dyspepsia, vomiting, anorexia, diarrhea, weight loss, gastrointestinal bleeding, peripheral edema and typically significant hypoalbuminemia secondary to a loss of albumin into the gastric lumen, as well as an exacerbated loss of enteric protein. ${ }^{1,5}$ Gastric fold thickening is the most notable feature of Ménétrier's disease. Nonetheless, this finding is nonspecific, being also found in infectious gastritis (i.e., Helicobacter pylori, cytomegalovirus, histoplasmosis and gastric syphilis), gastric neoplasms such as lymphoma and adenocarcinoma, Zollinger-Ellison syndrome, eosinophilic gastritis, infiltrative diseases such as sarcoidosis and amyloidosis, and gastric varices. ${ }^{5}$ It is important to highlight that, in our patient, all of these causes were excluded using the appropriate tests. The diagnostic procedure of choice is upper endoscopy showing giant rugal folds that involve the fundus and the body of the stomach, generally with antral sparing, confirmed by tissue diagnosis of biopsy material. ${ }^{1,4}$

Optimal treatment of this disease is elusive, because the condition is rare and controlled trials are lacking. Many pharmacological approaches have provided occasional therapeutic benefits but inconsistent, such as anti-secretory agents (e.g., histamine-2 blockers, proton pump inhibitors and anti-cholinergic drugs), glucocorticoids, octreotide, Helicobacter pylori eradication and monoclonal antibody against the epidermal growth factor receptor. ${ }^{3,4}$ Currently, subtotal or total gastrectomy seems to be the only curative treatment, but is reserved for individuals in whom medical management failed or who experienced severe complications such as refractory or persistent bleeding, persistent loss of protein, or if malignancy could not be excluded. ${ }^{1,5}$

Ménétrier's disease associated with AIP may pose a diagnostic challenge because both conditions can present overlapping features, which can make it difficult to es- tablish timely diagnosis and prompt treatment. For example, patients who present for care late in the course of AIP, after multiple relapses, or those in whom the initial presentation goes undiagnosed or misdiagnosed, may show features of exocrine pancreatic insufficiency including abdominal pain, diarrhea, weight loss, anemia and edema resulting from hypoalbuminemia caused by chronic protein malabsorption. All of these clinical findings can also be found in Ménétrier's disease. Therefore, in AIP patients presenting severe and persistent hypoproteinemia without apparent cause, clinicians need to consider Ménétrier's disease as a differential diagnosis. In this setting, endoscopic evaluation with histological examination of gastric biopsy material, including a full-thickness mucosal biopsy of the involved mucosa, may be helpful to establish prompt diagnosis allowing appropriate and timely therapy. ${ }^{4}$ We speculate that there may be some relation between AIP and Ménétrier's disease explained by the sharing of a common genetic factor.

Alternatively, Ménétrier's disease might be an extrapancreatic manifestation of AIP, as analogy of the association of AIP with other immune-mediated diseases such as IgG4-associated cholangitis, salivary gland disorders, mediastinal fibrosis, retroperitoneal fibrosis, tubulointerstitial disease, and inflammatory bowel disease. ${ }^{6}$

In summary, we herein described a case of severe hypoproteinemia as a harbinger of Ménétrier's disease associated with AIP. The patient was successfully treated with octreotide LAR and high-protein diet, which led to symptomatic remission and significant improvement of serum levels of albumin and total protein, as well as recovery of the nutritional status. Thus, in AIP patients presenting severe hypoproteinemia secondary to protein-losing gastroenteropathy, Ménétrier's disease should be considered as differential diagnosis and prompt endoscopic evaluation must be requested to rule out this condition.

\section{Conflict of interest}

The authors declare no conflict of interest.

\section{Resumo}

Hipoproteinemia grave como indicador de doença de Ménétrier na pancreatite autoimune

A doença de Ménétrier é uma condição extremamente rara, de etiologia desconhecida, caracterizada por hipertrofia da mucosa gástrica e gastropatia perdedora de proteína. Casos raros dessa patologia têm sido relatados em pacientes com doenças autoimunes. Até o momento, desconhecemos 
qualquer relato dessa doença associada à pancreatite autoimune (PAI). Descrevemos um caso de hipoproteinemia grave como indicador de doença de Ménétrier associada à PAI. O paciente foi tratado de forma satisfatória com octreotide e dieta hiperproteica, alcançando remissão sintomática, melhora significativa das concentrações de albumina e recuperação do estado nutricional. Portanto, em pacientes com PAI e hipoproteinemia grave e persistente, deve-se considerar a doença de Ménétrier como um diagnóstico diferencial. Nesses casos, a avaliação endoscópica com biópsia gástrica, incluindo biópsia de toda a espessura da mucosa, pode ser útil no estabelecimento do diagnóstico e do pronto início da terapêutica.
Palavras-chave: pancreatite autoimune, doença de Ménétrier, gastropatia perdedora de proteína.

\section{RefEREnCES}

1. Lambrecht NW. Ménétrier's disease of the stomach: a clinical challenge. Curr Gastroenterol Rep. 2011; 13(6):513-7.

2. Hemmings CT. Menetrier's disease in a patient with ulcerative colitis: a case report and review of the literature. Pathology. 2007; 39(2):282-3.

3. Anderson B, Sweetser S. Ménétrier disease and ulcerative colitis. J Clin Gastroenterol. 2015; 49(9):796-7.

4. Rich A, Toro TZ, Tanksley J, Fiske WH, Lind CD, Ayers GD, et al. Distinguishing Ménétrier's disease form its mimics. Gut. 2010; 59(12):1617-24.

5. Friedman J, Platnick J, Farruggia S, Khilko N, Mody K, Tyshkov M. Ménétrier disease. Radiographics. 2009; 29(1):297-301.

6. Madhani K, Farrell JJ. Autoimmune pancreatitis: an update on diagnosis and management. Gastroenterol Clin North Am. 2016; 45(1):29-43. 